Jurnal Kejuruteraan SI 1(4) 2018: 1-6

http://dx.doi.org/10.17576/jkukm-2018-si1(4)-01

\title{
Performance Investigation of High-Temperature Proton Exchange Membrane Fuel Cell
}

\author{
(Kajian Prestasi Sel Fuel Membran Pertukaran Proton Bersuhu Tinggi) \\ Mohamad Zaqwan Mohd Igbal ${ }^{\mathrm{a}}$, Masli Irwan Rosli ${ }^{\mathrm{a}, \mathrm{b}, \mathrm{c}^{*}}$ \\ ${ }^{a}$ Chemical Engineering Programme, \\ ${ }^{b}$ Research Centre for Sustainable Process Technology (CESPRO), \\ Faculty of Engineering \& Built Environment, \\ ${ }^{c} \mathrm{Fuel}$ Cell Institute \\ Universiti Kebangsaan Malaysia \\ Dedikarni Panuh \\ ${ }^{d}$ Department of Mechanical Engineering, \\ Universitas Islam Riau
}

\begin{abstract}
Awareness on the issues associated with the development of sustainable energy and climate change has significantly improved. The fuel cell has been considered an efficient and clean alternative power source. The principle operation on proton-exchange membrane fuel cells (PEMFCS) naturally leads to the development of water as a by-product of the reaction between hydrogen and oxygen. A computational fluid dynamics (CFD) model was developed to investigate the performance of high-temperature PEMFCS and the development of water profile. The CFD model was developed using ANSYS ${ }^{\circledR}$ Fluent software, ANSYS 18.0. The model was designed as a single straight channel measuring $2.4 \mathrm{~mm}$ in width, $2.88 \mathrm{~mm}$ in height and $125 \mathrm{~mm}$ in length. The simulation was carried out at the temperature range of $80^{\circ} \mathrm{C}$ to $120^{\circ} \mathrm{C}$ with an operating pressure of $200 \mathrm{kPa}$. Results were presented in the form of polarisation curve and contour of the $\mathrm{H}_{2} \mathrm{O}$ mass fraction at the gas channel mid-plane at different operating temperatures. At lower operating temperature ranges, namely $80^{\circ} \mathrm{C}$, the simulation results showed the higher performance of HT-PEMFC in term of current density compared to the higher operating temperature. The mass fraction of water was observed to be more concentrated at the anode gas channel compared to the cathode gas channel. The mass fraction of water at the anode and cathode gas channels increased with decreasing operating temperature from $120^{\circ} \mathrm{C}$ to $80^{\circ} \mathrm{C}$ that could indicate the possibility of water flooding in the HT-PEMFC components thus could affect the durability of the cell.
\end{abstract}

Keywords: HT-PEMFC; computational fluid dynamics; operating temperature

ABSTRAK

Kesedaran mengenai isu-isu yang berkaitan dengan pembangunan tenaga mampan dan perubahan iklim berkembang dengan ketara sekali. Sel fuel telah dianggap sebagai penjana kuasa alternatif yang cekap dan bersih. Operasi asas PEMFC secara umumnya membawa kepada pembentukan air sebagai produk sampingan hasil tindak balas antara gas hidrogen dan oksigen. Dalam kajian ini, satu model perkomputeran dinamik bendalir (CFD) telah dibangunkan untuk mengkaji prestasi sel fuel membran pertukaran proton bersuhu tinggi (HT-PEMFC) serta profil pembentukan air di dalam komponennya. Model CFD tersebut dibangunkan menggunakan perisian ANSYS ${ }^{\circledR}$ Fluent 18.0. Model ini telah direka bentuk sebagai saluran lurus tunggal dengan dimensi $2.4 \mathrm{~mm}$ lebar, $2.88 \mathrm{~mm}$ tinggi dan $125 \mathrm{~mm}$ panjang. Simulasi telah dijalankan pada julat suhu $80^{\circ} \mathrm{C}$ sehingga $120^{\circ} \mathrm{C}$ dengan tekanan operasi pada $200 \mathrm{kPa}$. Hasil simulasi ditunjukkan dan dibincangkan berpandukan lengkung pengutuban dan profil pecahan jisim air pada satah tengah saluran gas pada suhu pengoperasian yang berbezabeza. Pada suhu pengoperasian yang rendah khususnya pada suhu $80^{\circ} \mathrm{C}$, dapat ditunjukkan bahawa prestasi HT-PEMFC adalah lebih baik berbanding prestasi HT-PEMFC pada suhu pengoperasian yang lebih tinggi. Pecahan jisim air lebih banyak bertumpu di bahagian saluran gas anod berbanding saluran gas katod. Pecahan jisim air di bahagian anod dan katod meningkat dengan penurunan suhu pengoperasian bermula pada suhu $120^{\circ} \mathrm{C} \mathrm{ke} 80^{\circ} \mathrm{C}$ dan ini boleh menunjukkan kebarangkalian terjadinya fenomena pembanjiran dalam komponen HT-PEMFC yang akan merencat ketahanan sel.

Kata Kunci: HT-PEMFC; perkomputeran dinamik bendalir; suhu operasi 


\section{INTRODUCTION}

Awareness on energy and climate change has significantly improved. The development of sustainable energy is directed toward greenhouse effects due to the limited availability of gas emissions and fossil fuels (Carrette et al. 2000). Fuel cells have been recognised as a solution to combat greenhouse emission problems (Barbir 2013). Proton exchange membrane fuel cells (PEMFCs) feature the advantage as effective sources of power production with attractive energy transformation technologies, low operating temperature, high efficiency, zero emissions, quick start-up time and silent operation (Chen et al. 2016).

PEMFCs have undergone various investigations and research primarily for commercialisation purposes. These cells feature a large number of different applications that can be categorised into three areas: stationary power, transport and mobile power. Stationary power includes any application where fuel cells are operated at fixed locations for primary power, backup power or combined heat and power. Transport applications include motifs for passenger cars, buses and other fuel cell vehicles, special vehicles and material handling tools.

PEMFCs, also known as electrolyte polymer membrane fuel cells, use a water-based acid polymer membrane as an electrolyte with a platinum-based electrode. PEMFCs operate at relatively low temperatures (below $100^{\circ} \mathrm{C}$ ) and can adapt electrical output to meet dynamic power requirements. Such PEMFCs are commonly known as low-temperature PEMFCs (LT-PEMFC). Usually, the membrane used for LT-PEMFCs is based on perfluorosulfonic acid (Nafion) electrolytes (Su et al. 2013). This membrane possesses a hydrophobic phase that functions as a continuous phase and is important for structural integrity; it also includes hydrophilic phases for water reservoirs, which are a group of sulfonic acids (Yang et al. 2001). Water plays an important role as a charge carrier for proton conductivity because it promotes proton dissociation from sulfonic acid and provides a portable hydrogen proton in the Nafion membrane. Therefore, to maintain optimum performance, the membrane should always be hydrated.

Given the relatively low temperatures and the use of precious metal-based electrodes, PEMFCs must operate using pure hydrogen. The use of pure hydrogen poses a challenge due to high production costs and has therefore, become one of the major obstacles to various PEMFC applications. In addition, the absence of pure hydrogen can lead to serious poisoning in the electrocatalytic anode in PEMFCs (Rosli et al. 2016). The platinum (catalyst) used to enhance electrochemical reactions presents a significant relationship with carbon monoxide (CO); carbon monoxide adsorption to platinum surface causes electrocatalytic platinum poisoning (Yang et al. 2001).

Given that LT-PEMFC features remarkably low tolerance to pollutants in fuels, it requires pure hydrogen (99.999\%) to operate, where the hydrogen must be purified for example in CO removal system (Kamarudin et al. 2007), thereby leading to high operating costs resulting from pure hydrogen production (Chandan et al. 2013).

To overcome the problems of LT-PEMFC, the hightemperature proton exchange membrane fuel cells (HT-PEMFCs) have attracted the attention and interest of researchers around the world (Li et al. 2016). HT-PEMFC operation bridges the gap for this technology toward commercialisation. This finding is based on the improvement in HT-PEMFC performance with increased temperature and tolerance to carbon monoxide contaminants at high operating temperatures, especially in terms of improved kinetic reaction and thermal usage. In addition, with higher operating temperatures, some LTPEMFC issues related to water management in the design of the stack can be eliminated and altered with a simpler water management system (Rosli et al. 2016).

The membrane is one of the major components that play important roles in HT-PEMFC operation at high temperatures. The findings from previous studies demonstrated that phosphoric acid doping on membranebased polybenzimidazole (PBI) $\left(\mathrm{PBI}-\mathrm{H}_{3} \mathrm{PO} 4\right)$ can operate at temperatures up to $200^{\circ} \mathrm{C}$ (Zeis 2015). High operating temperatures are considered a potential solution to the issues of typical PEMFC operations.

In addition, the current collector and bipolar plates are also important components that must be considered in HTPEMFC. Due to elevated temperature in HT-PEMFC, the material degradations of the plates are also increased (Zhang 2006), and this must be minimized in order to prevent mechanical failure in HT-PEMFC operation. Bipolar plates are the components that separate each of the cells within the PEMFC stack, collect current, the water channels out of each cell and to humidify the gas (Davies et al. 2000). In general, bipolar plates are made of metallic and graphite material. Currently, for high temperature LT-PEMFC bipolar material is widely used in metal, to improve heat resistance, good electrical conductor, low cost, easy in machining, gas permeability and have good performance (Panuh et al. 2017).

The usage of higher temperature in the system mainly improves the kinetics of the electrochemical reaction, resulting in reduced membrane resistance, higher tolerance of pollutants, higher oxygen consumption more efficient power production and simpler system design (Sun et al. 2015). However, temperature control must also be considered as the durability of fuel cells will decline with increasing temperature and may increase the risk of acid leaching.

Operation at an acceptable temperature level in the short term is another factor that poses a challenge in commercializing HT-PEMFC, especially on start-up mode. This condition requires the HT-PEMFC system to operate at a fast start-up and in a constantly moving and stopping system.

Table 1 shows the research conducted by researchers at different operating temperatures. Zhang et al. (2007) studied the effects of temperature on cell performance at temperatures of $120^{\circ} \mathrm{C}-200^{\circ} \mathrm{C}$, whereas Wannek et al. (2008) conducted a study at the temperature range of $140^{\circ} \mathrm{C}-200^{\circ} \mathrm{C}$. The results of studies performed at different operating temperatures indicate that as temperature increases, membrane resistance decreases, thereby improving current density. 
TABLE 1. Different operating temperatures on HT-PEMFC system

\begin{tabular}{lc}
\hline \multicolumn{1}{c}{ Researcher } & Operating Temperature \\
\hline Zhang et al. (2007) & $120^{\circ} \mathrm{C}-200^{\circ} \mathrm{C}$ \\
Wannek et al. (2008) & $140^{\circ} \mathrm{C}-200^{\circ} \mathrm{C}$ \\
Ong et al. (2010) & $170^{\circ} \mathrm{C}$ \\
Oono et al. (2010) & $150^{\circ} \mathrm{C}, 170^{\circ} \mathrm{C}, 190^{\circ} \mathrm{C}$ \\
\hline
\end{tabular}

Zhang et al. (2007) compare the simulated and measured fuel cell performances at different temperatures for current densities less than $0.4 \mathrm{Acm}^{-2}$. The simulated and measured data for each curve are fairly consistent, confirming that the measured exchange current densities are reliable.

Different opinions have been suggested by Ong et al. (2010), he states that $170^{\circ} \mathrm{C}$ is the optimum temperature for the cell studied by his group. Oono et al. (2010) on the other hand examined operating temperatures on sets of $150^{\circ} \mathrm{C}$, $170^{\circ} \mathrm{C}$ and $190^{\circ} \mathrm{C}$ to investigate the durability of HT-PEMFC.

CFD simulation investigations have been conducted in the past to predict the performance of many types of fuel cells to study the influencing factors and its design parameters. The approach has been used to study the effect of different type of flow fields for a direct methanol fuel cell (Maslan et al. 2015) and to perform numerical analysis of the new design of the PEMFC components (Lim et al. 2017). This work aims to investigate the effect of temperature on the performance of fuel cells. A 3D CFD model of HT-PEMFCs is developed by using ANSYS commercial software (ANSYS 2012).

\section{METHODOLOGY}

\section{HT-PEMFC MODEL DEVELOPMENT PROCESS}

The simulation was performed on the four main layers of a fuel cell: gas channel, a gas diffusion layer, membrane and catalyst layer. These layers were drawn in 3D using ANSYS Fluent ${ }^{\circledR} 18.0$ software based on the selected dimensions that within the acceptable dimension ranges of PEMFC of referred to in Table 2. The model was based on a single straight channel fuel cell with $125 \mathrm{~mm}$ of length. Figure 1 the CFD model that has been developed in this study.

TABLE 2. HT-PEMFC single straight channel geometry model

\begin{tabular}{lc}
\hline \multicolumn{1}{c}{ Component } & Dimension (mm) \\
\hline Current collector width & 2.4 \\
Current collector height & 1.2 \\
Gas channel width & 0.8 \\
Gas channel height & 0.6 \\
Gas diffusion layer height & 0.21 \\
Catalyst layer height & 0.012 \\
Membrane height & 0.036 \\
\hline
\end{tabular}




\section{RESULTS AND DISCUSSION}

\section{CFD MODEL VALIDATION}

The CFD HT-PEMFC model was verified on the basis of the comparison between the polarisation curve trend. Current density reached $0.326 \mathrm{~A} \mathrm{~cm}^{-2}$ at the operating temperature of $120^{\circ} \mathrm{C}$, relative humidity of $0 \%$, cell voltage of $0.65 \mathrm{~V}$ and 200 iterations. The current density value from simulation differed from that of the experiment $\left(0.39 \mathrm{~A} \mathrm{~cm}^{-2}\right)$ with an error difference value of $16 \%$. This error might be because of the different open circuit voltage that has been set in simulation compare to the measured in the experimental work. Figure 2 shows the polarisation curve of the simulation study and comparison of experimental data with that by Zhang et al (2007).

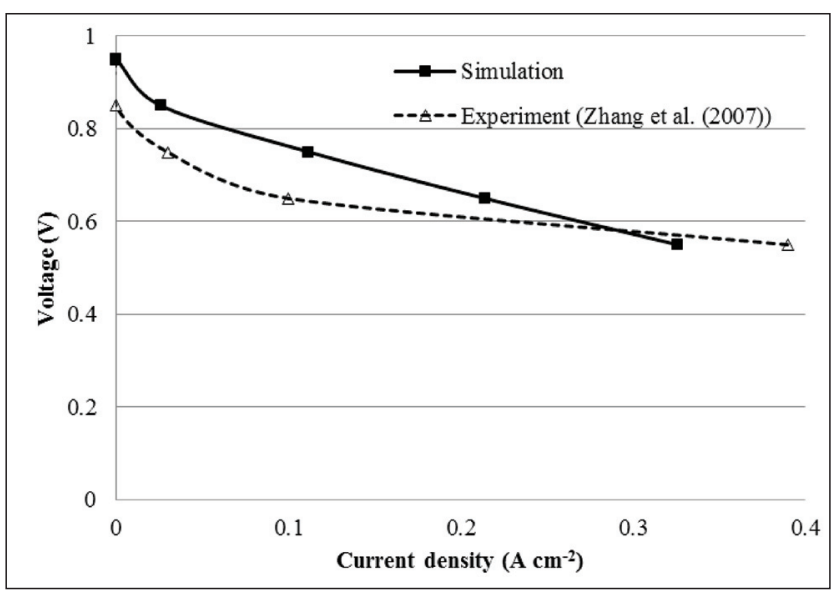

FIGURE 2. Polarisation curve HT-PEMFC model at $120^{\circ} \mathrm{C}$

\section{POLARISATION CURVE AT DIFFERENT TEMPERATURES}

Figure 3 shows the comparison of HT-PEMFC performance at different temperatures $\left(80^{\circ} \mathrm{C}, 90^{\circ} \mathrm{C}, 100^{\circ} \mathrm{C}, 110^{\circ} \mathrm{C}\right.$ and $120^{\circ} \mathrm{C}$ ) in the polarisation curve. In this comparison, HTPEMFC was operated using pure hydrogen gas on the anode and pure oxygen gas in the cathode inlet without dampening (Relative humidity $=0 \%$ ) and at an operating pressure of $200 \mathrm{kPa}$.

Referring to Figure 3, at operating temperatures of $80^{\circ} \mathrm{C}, 90^{\circ} \mathrm{C}, 100^{\circ} \mathrm{C}, 110^{\circ} \mathrm{C}$ and $120^{\circ} \mathrm{C}$, the current densities at $0.65 \mathrm{~V}$ totalled $0.321,0.235,0.201,0.202$ and $0.214 \mathrm{~A}$ $\mathrm{cm}^{-2}$, respectively. These simulation results show that the performance of HT-PEMFC decrease with the increment of operating temperatures at this typical operating voltage of HT-PEMFC and at higher current density regions.

At operating temperatures of $80^{\circ} \mathrm{C}$ and $90^{\circ} \mathrm{C}$, the polarisation curve deviated and exhibited a relatively significant movement at low current density, thereby showing better fuel cell performance compared with that at operating temperatures of $100^{\circ} \mathrm{C}, 110^{\circ} \mathrm{C}$ and $120^{\circ} \mathrm{C}$. This finding is contrary to that usually obtained for HT-PEMFC, in which high water content causes to decrease membrane conductivity at low temperatures. Deviations in data occurred due to high relative humidity values at low operating temperatures. According to He et al. (2003), the increase in relative humidity at low operating temperature contributes to increased membrane conductivity although such increment is nonsignificant. Given that relative humidity at $80^{\circ} \mathrm{C}$ and $90^{\circ} \mathrm{C}$ was higher than those at $100^{\circ} \mathrm{C}, 110^{\circ} \mathrm{C}$ and $120^{\circ} \mathrm{C}$, membrane conductivity was more likely to lean toward relative humidity cells rather than toward temperature.

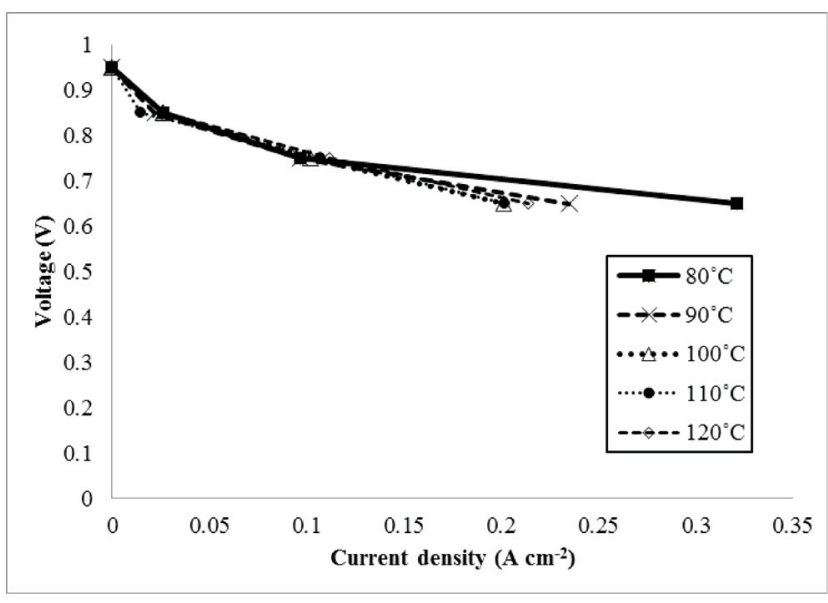

FIGURE 3. Polarisation curve at different temperatures of $80^{\circ} \mathrm{C}$, $90^{\circ} \mathrm{C}, 100^{\circ} \mathrm{C}, 110^{\circ} \mathrm{C}$ and $120^{\circ} \mathrm{C}$

\section{WATER DISTRIBUTION AT DIFFERENT TEMPERATURES}

Figure 4 shows the mass fraction of water in a single straight-channel HT-PEMFC based on the mid-plane crosssection at temperatures of $80^{\circ} \mathrm{C}, 90^{\circ} \mathrm{C}, 100^{\circ} \mathrm{C}, 110^{\circ} \mathrm{C}$ and $120^{\circ} \mathrm{C}$. Gas (pure hydrogen) entered through the anode inlet channel, whereas gas (pure oxygen) entered through the cathode channel as showed in the arrow directions. Water was produced, and the mass fraction of water increased with increasing distance from the channel. At temperatures of $80^{\circ} \mathrm{C}$ and $90^{\circ} \mathrm{C}$, the mass fraction of water was more concentrated at the anode gas channel. The mass fraction of water in the anode decreased with the increase in operating temperatures from $80^{\circ} \mathrm{C}$ to $120^{\circ} \mathrm{C}$.

Based on Figure 4, the mass fraction of water was observed more at an operating temperature of $80^{\circ} \mathrm{C}$ and not observed at an operating temperature of $120^{\circ} \mathrm{C}$. The mass fraction of water was high at an operating temperature of $80^{\circ} \mathrm{C}$ and decreased with increasing temperature. This finding is due to the higher current densities produced at lower operating temperatures thus produce more product water from the electrochemical reaction. The higher mass fractions of water observed at lower operating temperature ranges could indicate the possibility of water flooding in the HT-PEMFC components thus could affect the durability of the cell in long hours of operation.

Figure 5 shows the mass fraction of hydrogen and oxygen through the mid-plane at operating temperatures of $80^{\circ} \mathrm{C}$, $90^{\circ} \mathrm{C}, 100^{\circ} \mathrm{C}, 110^{\circ} \mathrm{C}$ and $120^{\circ} \mathrm{C}$. Hydrogen mass fraction was observed at the anode gas channel, whereas oxygen mass fraction was noted at the cathode gas channel. By increasing the operating temperatures, there is less hydrogen and oxygen 
a)

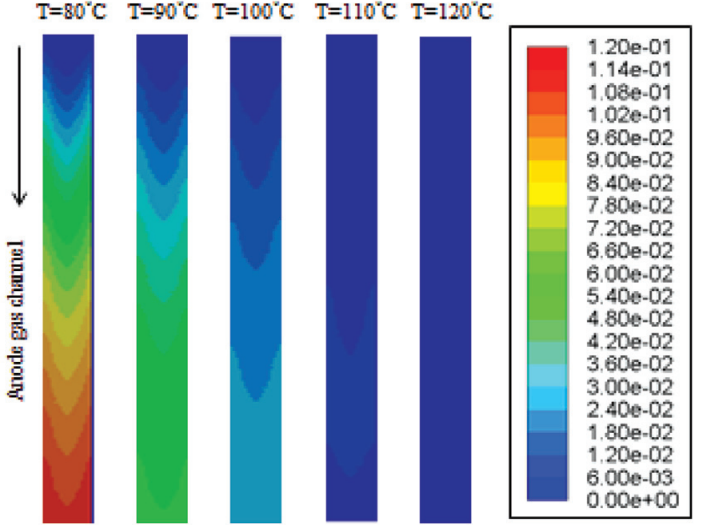

b)

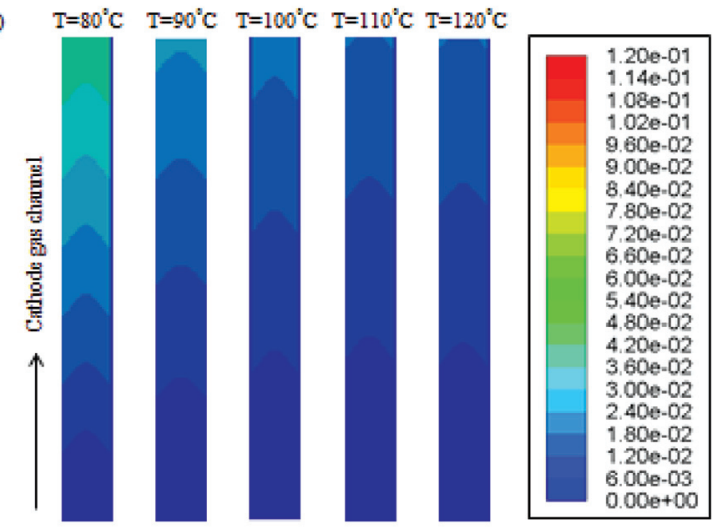

FIGURE 4. Water mass fraction at the gas channel (a) anode and (b) cathode at a temperature of $80^{\circ} \mathrm{C}, 90^{\circ} \mathrm{C}, 100^{\circ} \mathrm{C}$, $110^{\circ} \mathrm{C}$ and $120^{\circ} \mathrm{C}$

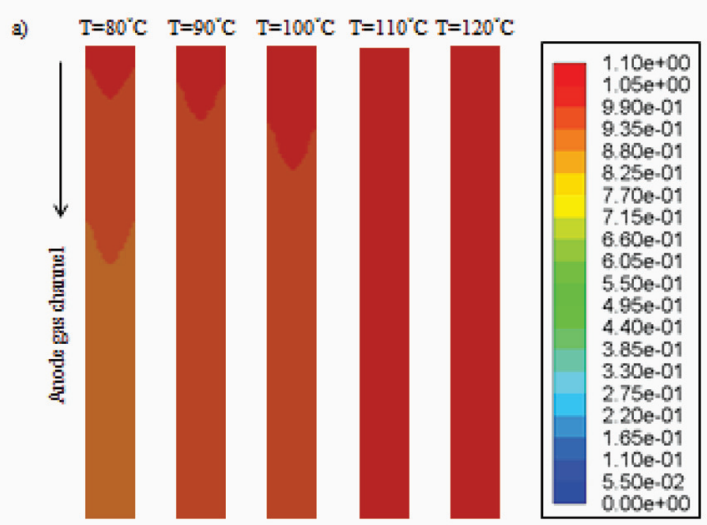

b) $\mathrm{T}=80^{\circ} \mathrm{C} \quad \mathrm{T}=90^{\circ} \mathrm{C} \quad \mathrm{T}=100^{\circ} \mathrm{C} \quad \mathrm{T}=110^{\circ} \mathrm{C} \quad \mathrm{T}=120^{\circ} \mathrm{C}$

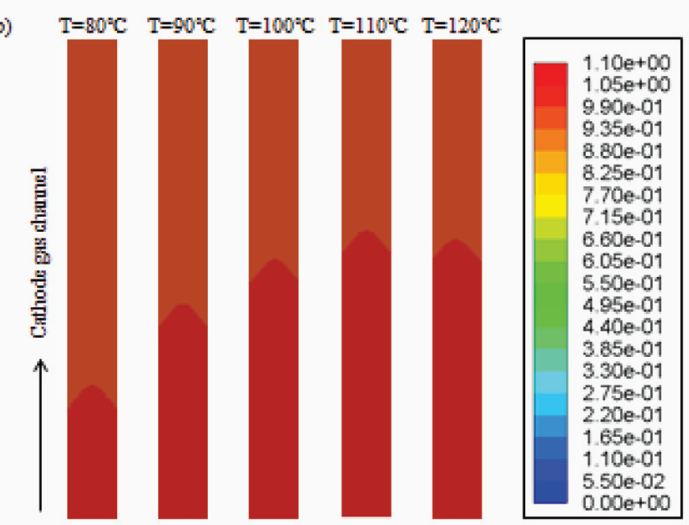

FIGURE 5. Mass fraction (a) Hydrogen and (b) Oxygen at a temperature of $80^{\circ} \mathrm{C}, 90^{\circ} \mathrm{C}, 100^{\circ} \mathrm{C}, 110^{\circ} \mathrm{C}$ and $120^{\circ} \mathrm{C}$ consumptions cause of the lower rate of electrochemical reactions and this is shown by lower current density produced at lower operating temperatures in Figure 3.

\section{CONCLUSION}

Based on observations in the simulations, at operating temperatures of $80^{\circ} \mathrm{C}$, the mass fraction of water was more concentrated at the anode gas channel. The mass fraction of water at the anode decreased with increasing operating temperatures of $80^{\circ} \mathrm{C}, 90^{\circ} \mathrm{C}, 100^{\circ} \mathrm{C}, 110^{\circ} \mathrm{C}$ and $120^{\circ} \mathrm{C}$. The mass fraction of water was high at an operating temperature of $80^{\circ} \mathrm{C}$ and decreased with increasing temperature due to the higher current density at a lower operating temperature. Current density increases as operating temperature decreased. However, the higher mass fractions of water observed at lower operating temperature ranges could indicate the possibility of water flooding in the HT-PEMFC components thus could affect the durability of the cell.

\section{ACKNOWLEDGEMENT}

The authors would like to thank Universiti Kebangsaan Malaysia for their financial support under the grant GUP2016-041.

\section{REFERENCES}

ANSYS 2012. ANSYS FLUENT Fuel Cell Modules Manual Release 14.5. Province: ANSYS Inc.

Barbir, F. 2013. PEM Fuel Cells: Theory and Practice. $2^{\text {nd }}$ edition. London: Elsevier Inc. Academic Press.

Carrette, L., Friedrich, K. A. \& Stimming, U. 2000. Fuel Cells: Principles, Types, Fuels, and Applications. ChemPhysChem 1: 162-193.

Chandan, A., Hattenberger, M., El-kharouf, A., Du, S., Dhir, A., Self, V., Pollet, B. G., Ingram, A. \& Bujalski, W. 2013. High temperature (HT) polymer electrolyte membrane fuel cells (PEMFC) - A review. Journal of Power Sources 231: 264-278.

Chen, Y., Enearu, O. L., Montalvao, D. \& Sutharssan, T. 2016. A Review of Computational Fluid Dynamics Simulations on PEFC Performance. Journal of Applied Mechanical Engineering 5(6). DOI: 10.4172/2168-9873.1000241.

Davies, D. P., Adcock, P. L., Turpin, M. \& Rowen, S. J. 2000. Bipolar plate materials for solid polymer fuel cells. Journal of Applied Electrochemistry 30(1): 101-105.

He, R., Li, Q., Xiao, G. \& Bjerrum, N. J. 2003. Proton conductivity of phosphoric acid doped polybenzimidazole and its composites with inorganic proton conductors. Journal Membrane Science 226(1-2): 169-184.

Kamarudin, S. K., Daud, W. R. W. \& Mohammad, A. W. 2007. Development of short cut design method for CO removal system. Jurnal Kejuruteraan 19: 63-76.

Li, Q., Aili, D., Hjuler, H. A. \& Jensen, J. O. 2016. High Temperature Polymer Electrolyte Membrane Fuel Cells 
- Approaches, Status, and Perspectives. Switzerland Springer.

Lim, B. H., Majlan, E. H. Daud, W. R. W., Rosli, M. I. \& Husaini, T. 2017. Numerical analysis of modified parallel flow field designs for fuel cells. International Journal of Hydrogen Energy 42: 9210-9218.

Maslan, N. H., Rosli, M. I., Goh, C. W. \& Masdar, M. S. 2015. Computational fluid dynamics simulation of the flow field of direct methanol fuel cells. International Journal of Mechanical and Mechatronics Engineering 15(5): 114-125.

Ong, A. L., Jung, G. B., Wu, C. C. \& Yan, W. M. 2010. Single-step fabrication of ABPBI-based GDE and study of its MEA characteristics for high-temperature PEM fuel cells. International Journal of Hydrogen Energy 35(15): 7866-7873.

Oono, Y., Fukuda, T., Sounai, A. \& Hori, M. 2010. Influence of operating temperature on cell performance and endurance of high temperature proton exchange membrane fuel cells. Journal of Power Sources 195(4): 1007-1014.

Panuh, D., Dweiri, R. \& Sahari, J. 2017. Effect of processing parameters on electrical properties of polypropylene/ graphite composite plates. International Journal of Microstructure and Materials Properties 12(1-2): 1224.

Rosli, R. E., Sulong, A. B., Daud, W. R. W., Zulkifliey, M. A., Husaini, T., Rosli, M. I., Majlan, E. H. \& Haque, M. A. 2016. A review of high-temperature proton exchange membrane fuel cell (HT-PEMFC) system. International Journal of Hydrogen Energy 42(14): 9293-9314.

Su, H., Pasupathi, S., Bladergroen, B., Linkov, V. \& Pollet, B. G. 2013. Performance investigation of membrane electrode assemblies for high temperature proton exchange membrane fuel cell. Journal of Power and Energy Engineering 1(5): 95-100.

Sun, H., Xie, C., Chen, H. \& Almheiri, S. 2015. A numerical study on the effects of temperature and mass transfer in high temperature PEM fuel cells with ab-PBI membrane. Applied Energy 160: 937-944.

Wannek, C., Dohle, H., Mergel, J. \& Stolten, D. 2008. Novel VHT-PEFC MEAs based on ABPBI membranes for APU applications. ECS Transactions 12(1): 29-39.
Yang, C., Costamagna, P., Srinivasan, S., Benziger, J. \& Bocarsly, A. B. 2001. Approaches and technical challenges to high temperature operation of proton exchange membrane fuel cells. Journal of Power Sources 103: 1-9.

Zeis, R. 2015. Materials and characterization techniques for high-temperature polymer electrolyte membrane fuel cells. Beilstein Journal of Nanotechnology 6: 68-83.

Zhang, J., Tang, Y., Song, C. \& Zhang, J. 2007. Polybenzimidazole membrane-based PEM fuel cell in the temperature range of $120^{\circ} \mathrm{C}-200^{\circ} \mathrm{C}$. Journal of Power Sources 172(1): 163-171.

Zhang, J., Xie, Z., Zhang, J., Tang, Y., Song, C., Navessin, T., Shi, Z., Song, D., Wang, H., Wilkinson, D. P., Liu, Z. S., \& Holdcroft, S. 2006. High temperature PEM fuel cells. Journal of Power Sources 160(2): 872-891.

*Masli Irwan Rosli,

Research Centre for Sustainable Process Technology (CESPRO),

Faculty of Engineering \& Built Environment, Universiti Kebangsaan Malaysia,

43600 UKM Bangi, Selangor, Malaysia.

Mohamad Zaqwan Mohd Igbal

Chemical Engineering Programme,

Faculty of Engineering \& Built Environment,

Universiti Kebangsaan Malaysia,

43600 UKM Bangi, Selangor, Malaysia.

Dedikarni Panuh

Department of Mechanical Engineering, Universitas Islam Riau, Kota Pekanbaru, Riau 28284, Indonesia.

*Corresponding author; email: masli@ukm.edu.my

Received date: $11^{\text {th }}$ April 2018

Accepted date: $17^{\text {th }}$ July 2018

Online First date: $1^{\text {st }}$ October 2018

Published date: $30^{\text {th }}$ November 2018 